Asbur, Y. • M. Ariyanti

\title{
Peran konservasi tanah terhadap cadangan karbon tanah, bahan organik, dan pertumbuhan kelapa sawit (Elaeis guineensis jacq.)
}

\section{The role of soil conservation to soil carbon stocks, organic matter, and oil palm (Elaeis guineensis jacq.) Growth}

Diterima : 11 Desember 2017/Disetujui : 18 Desember 2017 / Dipublikasikan : 30 Desember 2017

CDepartment of Crop Science, Padjadjaran University

\begin{abstract}
Two methods for Soil conservation in oil palm plantations are by vegetatively and mechanically. Vegetatively method is generally using plants that grow at oil palm plantation such as Asystasia gangetica and Nephrolepis biserrata as cover crop, while mechanically is develop the ridge terrace by cutting the slope. This research aims to determine the role of soil conservation on soil carbon stock, organic matter, and oil palm growth. The research was conducted in mature oil palm plantation (planted year 2005), PTPN VII, South Lampung from August, 2014 until Aprl, 2015.The research used nested design with 6 repetitions nested in each treatment. The treatment consists of a ridge terrace (without and with ridge terrace), and cover crop (without and with cover crop N.biserrata, andA.gangetica). The results showed that the soil conservation application using cover crop and ridge terrace increased carbon stock and soil organic matter compared without soil conservation, respectively of $4.44 \mathrm{t} / \mathrm{ha}$ and $0.69 \%$ (N.biserrata without ridge terrace); 5.28 $\mathrm{t} / \mathrm{ha}$ and $0.83 \%$ (A.gangetica without ridge terrace); $7.04 \mathrm{t} / \mathrm{ha}$ and $1.10 \%$ (ridge terrace without cover crop); $10.45 \mathrm{t} / \mathrm{ha}$ and $1.64 \%$ (N.biserrata with ridge terrace); $11.33 \mathrm{t} / \mathrm{ha}$ and $1.78 \%$ (A.gangetica without ridge terrace). Soil conservation application also affects the growth of oil palm, especially the average of rachis length and the number of broken leaves.
\end{abstract}

Keywords :Nephrolepis biserrata, Asystasia gangetica, cover crop, ridge terrace

\footnotetext{
Dikomunikasikan oleh Yudithia Maxiselly

Asbur, Y. $^{1} \cdot$ M. Ariyanti $^{2}$

1) Program Studi Agrotekbologi, Fakultas Pertanian,

Universitas Islam Sumatera Utara. Jl. Karya Wisata

Gedung Johor, Medan-20144, Sumatera Utara, Indonesia

2) Departemen Budidaya Pertanian, Fakultas Pertanian,

Universitas Padjadjaran. Jl. Raya Bandung-Sumedang

$\mathrm{km} .21$, Jatinangor, Jawa Barat, Indonesia

Korespondensi: yenni.asbur@fp.uisu.ac.id
}

Sari Penerapan konservasi tanah di perkebunan kelapa sawit dapat dilakukan secara vegetatif dan mekanik. Secara vegetatif dengan memanfaatkan tanaman yang banyak tumbuh di bawah tegakan kelapa sawit seperti Asystasia gangetica dan Nephrolepis biserrata sebagai tanaman penutup tanah, sedangkan secara mekanik dengan memotong panjang lereng melalui pembuatan teras gulud. Penelitian ini bertujuan mengetahui peran konservasi tanah terhadap cadangan karbon tanah, bahan organik, dan pertumbuhan kelapa sawit. Penelitian dilaksanakan dari Agustus 2014April 2015 di perkebunan kelapa sawit (tahun tanam 2005) PTPN VII, Lampung Selatan. Penelitian menggunakan rancangan tersarang faktorial dengan enam ulangan tersarang di dalam perlakuan. Perlakuan terdiri dari teras gulud (tanpa teras gulud; dengan teras gulud), dan tanaman penutup tanah (tanpa tanaman penutup tanah; N.biserrata; A.gangetica). Hasil penelitian menunjukkan penerapan konservasi tanah menggunakan tanaman penutup tanah dan teras gulud di perkebunan kelapa sawit meningkatkan cadangan karbon dan bahan organik tanah dibandingkan tanpa konservasi tanah, berturutturut sebesar $4.44 \mathrm{t} /$ ha dan $0.69 \%$ ( $N$. biserrata tanpa teras gulud); $5.28 \mathrm{t} /$ ha dan $0.83 \%$ (A. gangetica tanpa teras gulud); $7.04 \mathrm{t} /$ ha dan $1.10 \%$ (teras gulud tanpa tanaman penutup tanah); 10.45 $\mathrm{t} /$ ha dan $1.64 \%$ ( $N$. biserrata dengan teras gulud); $11.33 \mathrm{t} /$ ha dan $1.78 \%$ (A. gangetica tanpa teras gulud). Penerapan konservasi tanah juga berpengaruh terhadap pertumbuhan kelapa sawit, terutama rataan panjang rachis dan jumlah pelepah sengkleh.

Kata kunci : Nephrolepis biserrata, Asystasia gangetica, tanaman penutup tanah, teras gulud 


\section{Pendahuluan}

Kelapa sawit (Elaeis guineensis Jacq.) merupakan salah satu tanaman perkebunan yang mempunyai peran penting bagi subsektor perkebunan, tetapi cara pengelolaan perkebunan kelapa sawit di Indonesia selalu menjadi black campaign di dunia internasional, terutama negara-negara di Eropa dan Amerika.

Penerapan pertanian konvensional telah diketahui berkontribusi terhadap perubahan iklim melalui peningkataan gas rumah kaca, termasuk $\mathrm{CO}_{2}$, sehingga penerapan konservasi tanah pada bidang pertanian merupakan langkah wajib yang harus dilaksanakan sesuai dengan UU No. 34 tahun 2014 tentang konservasi tanah dan air.

Pembuatan teras gulud merupakan salah satu tindakan konservasi tanah secara mekanik yang bertujuan menghambat erosi dan aliran permukaan sehingga mencegah kehilangan hara, serta menampung dan meresapkan air yang mengalir sebagai aliran permukaan. Menurut Arsyad (2010), teras gulud merupakan penyempurnaan bentuk guludan dengan dibuatnya saluran di atas guludan sehingga dapat menyalurkan air dengan kecepatan yang relatif lambat dan tidak merusak saluran, mencegah air tergenang di lapangan, menurunkan permukaan air tanah, sehingga perkembangan akar tanaman tidak terganggu serta mencegah terjadinya pencucian pupuk.

Beberapa hasil penelitian menunjukkan bahwa pada perkebunan kelapa sawit yang diberi perlakuan teras gulud dengan mulsa vertikal dapat menurunkan aliran permukaan, overland flow, dan erosi pada tanah (Muslim, 2008), sehingga juga dapat menurunkan kehilangan hara yang tercuci bersamaan dengan erosi dan aliran permukaan. Aplikasi teras gulud dan rorak yang dilengkapi dengan mulsa vertikal juga memberikan pengaruh positif terhadap jumlah pelepah daun, jumlah tandan, rataan berat tandan, dan produksi TBS kelapa sawit (Murtilaksono et al., 2007). Hal ini karena aplikasi tersebut dapat meningkatkan cadangan air tanah untuk pemenuhan kebutuhan air dan hara tanaman, sehingga produksi kelapa sawit dapat dipertahankan. Hasil penelitian Pratiwi (2008), menunjukkan bahwa aplikasi teras gulud dan rorak mampu menyimpan cadangan air tanah tahunan lebih besar, serta meningkatkan produksi tandan kelapa sawit (TBS).
Selain pembuatan teras gulud, penggunaan tanaman penutup tanah juga merupakan salah satu teknik dalam penerapan konservasi tanah secara vegetatif yang di antaranya bertujuan untuk meningkatkan potensi penyerapan karbon organik tanah serta mengurangi perubahan iklim (Liebig et al., 2012). Tanaman penutup tanah berperan dalam meningkatkan penyerapan karbon organik tanah, memperbaiki kualitas tanah dan air dengan mengurangi kehilangan unsur hara dan erosi tanah (Miguez dan Bollero, 2005; Scholberg et al., 2010; Yenni et al., 2016).

Jenis tanaman yang dapat digunakan sebagai tanaman penutup tanah dipilih dan dikelola berdasarkan kebutuhan serta tujuan penggunaanya yang dipengaruhi oleh faktor biologis, lingkungan, sosial, budaya dan ekonomi dari sistem perkebunannya (Snapp et al., 2005). Asystasia gangetica (L.) T. Anderson dan Nephrolepis biserrata merupakan gulma yang banyak dijumpai di perkebunan kelapa sawit, terutama di PTPN VII, Lampung Selatan (Ariyanti et al., 2016) mempunyai beberapa manfaat penting bagi pengembangan perkebunan kelapa sawit secara berkelanjutan.

$N$. biserrata merupakan tanaman yang mudah terdekomposisi (Ariyanti et al., 2014), dapat meningkatkan kandungan C-organik dan hara N, P, K tanah berturut-turut sebesar 11.3\%, $41 \%, 11 \%$, 93\% selama terdekomposisi (Ariyanti et al., 2015a), meningkatkan kadar air tanah (Ariyanti et al., 2015a), serta mengurangi defisit air selama musim kering melalui neraca airnya (Ariyanti et al., 2015b; Ariyanti et al., 2016a). A. gangetica juga cepat terdekomposisi, yaitu dalam waktu 30 hari sudah terdekomposisi sebesar 90.0\%-96.6\% (Yenni et al., 2014), tahan terhadap naungan (Yenni et al., 2015a), meningkatkan ketersedian C-organik dan hara N, P, K tanah berturut-turut sebesar $27.83 \%, 31.58 \%$, 37.66\%, $34.62 \%$ (Yenni et al., 2016b), mengurangi erosi dan kehilangan hara N, P, K tanah (Yenni et al., 2016a), serta meningkatkan hara N, P, K tanah melalui neraca haranya (Yenni et al., 2015b).

Secara kuantitatif, walaupun kandungan hara yang berasal dari tanaman penutup tanah rendah namun tanaman penutup tanah memiliki keunggulan lain yaitu dapat memperbaiki sifat fisik, kimia dan biologi tanah, sehingga mampu menjaga keseimbangan hara dan meningkatkan stok karbon di dalam tanah (Reicosky and Forcella, 1998). Hasil penelitian Maswar (2009) pada perkebunan kelapa sawit rakyat di Desa Suak Raya, Kecamatan Johan Pahlawan, 
kabupaten Aceh Barat menunjukkan bahwa setiap tahunnya pelepah dan daun sawit serta biomassa gulma berpotensi mengembalikan karbon ke lahan (sebagai stok karbon) berkisar antara 1.40-1.86 t/ha dari pelepah dan daun sawit serta 7.99-10.37 t/ ha dari biomassa gulma.

Penelitian konservasi tanah secara mekanik dengan pembuatan teras gulud sudah banyak dilakukan dan memberikan hasil yang terbaik, namun penelitian konservasi tanah secara vegetatif dengan memanfaatkan gulma lokal sebagai tanaman penutup tanah masih sangat minim, sehingga penelitian ini bertujuan untuk mengetahui peran konservasi tanah secara mekanik dan vegetatif dalam meningkatkan cadangan karbon tanah, bahan organik, dan pertumbuhan kelapa sawit di perkebunan kelapa sawit menghasilkan.

\section{Bahan Dan Metode}

Penelitian dilaksanakan di Afdeling I (tahun tanam 2005) Unit Usaha (UU) Rejosari PT Perkebunan Nusantara (PTPN) VII, Kecamatan Natar, Kabupaten Lampung Selatan dari bulan Agustus 2014-April 2015.

Metode penelitian menggunakan rancangan tersarang (nested design) enam ulangan dengan ulangan tersarang dalam perlakuan. Rancangan ini merupakan rancangan faktorial yang terdiri dari perlakuan teras gulud dan tanaman penutup tanah. Perlakuan teras gulud (G) terdiri dari dua taraf, yaitu tanpa teras gulud $\left(G_{0}\right)$ dan dengan teras gulud $\left(G_{1}\right)$, sedangkan perlakuan tanaman penutup tanah $(\mathrm{T})$ terdiri dari tiga perlakuan, yaitu tanpa tanaman penutup tanah $\left(\mathrm{T}_{0}\right)$, ditanami tanaman penutup tanah $N$. biserrata $\left(\mathrm{T}_{1}\right)$, dan ditanami tanaman penutup tanah $A$. gangetica $\left(\mathrm{T}_{2}\right)$.

Petak percobaan dibuat dengan ukuran 20 $\mathrm{m} \times 15 \mathrm{~m}$ dan pembuatan teras gulud searah kontur pada setiap interval vertikal $80 \mathrm{~cm}$. Ketinggian, lebar dan kedalaman saluran guludan masing-masing sekitar $30 \mathrm{~cm}$ (Gambar 1). Pengambilan sampel tanah pada setiap percobaan dilakukan dengan menggunakan bor tanah pada kedalaman $0-10 \mathrm{~cm}$ dan dianalisis kandungan C-organik tanah menggunakan metode Walkley and Black.

Cadangan karbon tanah dihitung menggunakan persamaan Lugina et al., (2011):

$$
\mathrm{Ct}=\sum(\% \operatorname{Corg} x p \times K d) \times 100
$$

Keterangan :

$\mathrm{Ct}=$ Cadangan karbon tanah $(\mathrm{t} / \mathrm{ha})$

$\mathrm{Kd}=$ Kedalaman contoh tanah $(\mathrm{cm})$

$p=$ Bulk density tanah $\left(\mathrm{g} / \mathrm{cm}^{3}\right)$

$\% \mathrm{C}=$ Berdasarkan hasil analisis tanah

$100=$ Faktor konversi dari $\mathrm{g} / \mathrm{cm}^{3}$ ke $\mathrm{t} / \mathrm{ha}$

Kandungan bahan organik tanah dihitung dari kandungan C-organik tanah menggunakan persamaan dalam Hardjowigeno (2010) :

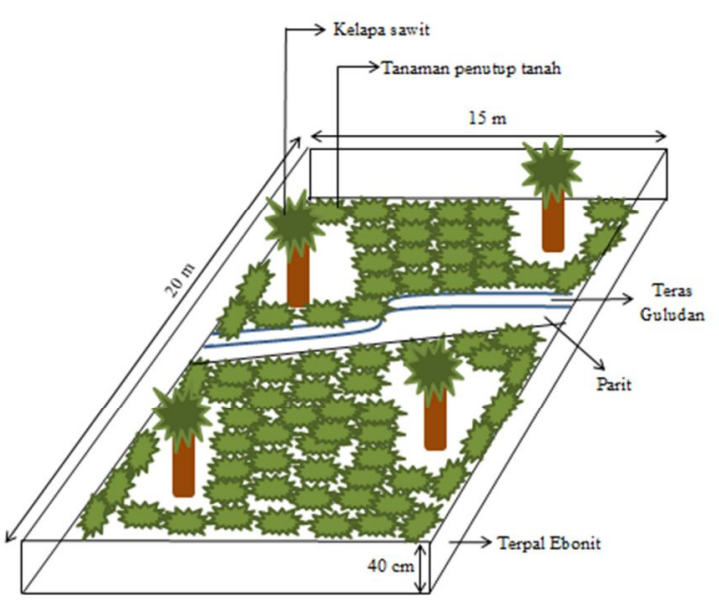

A

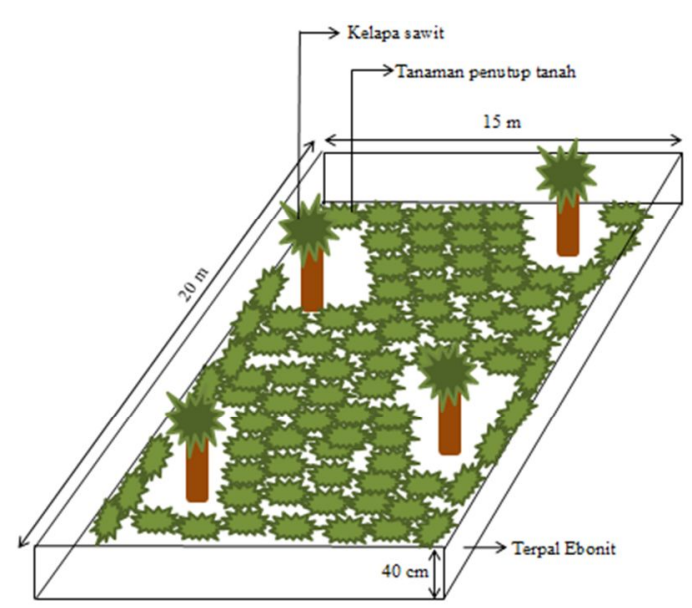

B

Gambar 1. Sketsa petak percobaan dengan ukuran $20 \mathrm{~m} \times 15 \mathrm{~m}$ : petak percobaan dengan teras gulud (A) dan tanpa teras gulud (B). 
Data hasil pengamatan dianalisis menggunakan uji $\mathrm{F}$ dan dilanjutkan dengan uji Beda Nyata Terkecil (BNT) pada taraf 5\%.

\section{Hasil dan Pembahasan}

Pendugaan cadangan karbon tanah sangat penting untuk mengetahui berapa banyak karbon tanah yang dapat disimpan, baik secara alami maupun yang dikelola dalam sistem pertanian. Tanah merupakan gudang karbon terpenting dalam jangka panjang pada ekosistem daratan, karena tanah mengakumulasi karbon lebih besar daripada jumlah karbon di dalam biomassa tanaman dan atmosfer (Tarnocai et al., 2009). Karbon yang tersimpan di dalam tanah juga dapat berkontribusi untuk pencegahan emisi gas rumah kaca (Follet et al., 2009), dan sebagai salah satu indikator penting dalam menentukan kualitas tanah (Islam and Weil, 2000), karena peranannya dalam menentukan sifat fisik, kimia, maupun biologi tanah (Hou et al., 2012; Liu et al., 2011; Bationo et al., 2006), sehingga karbon yang tersimpan dalam tanah harus dipelihara dan dipertahankan. Hasil analisis statistik cadangan karbon tanah pada perlakuan teras gulud dan tanaman penutup tanah disajikan pada Tabel 1 .

Tabel 1 menunjukkan bahwa cadangan karbon tanah pada perlakuan teras gulud dan tanaman penutup tanah lebih tinggi dibandingkan pada perlakuan tanpa teras gulud dan tanpa tanaman penutup tanah. Cadangan karbon tanah tertinggi dijumpai pada perlakuan teras gulud dengan tanaman penutup tanah $A$. gangetica $\left(\mathrm{G}_{1} \mathrm{~T}_{2}\right)$ dan $N$. biserrata $\left(\mathrm{G}_{1} \mathrm{~T}_{1}\right)$, yaitu berturut-turut sebesar 11.33 ton $\mathrm{C} /$ ha dan 10.45 ton $\mathrm{C} / \mathrm{ha}$, sedangan cadangan karbon tanah terendah dijumpai pada perlakuan tanpa teras gulud tanpa tanaman penutup tanah $\left(\mathrm{G}_{0} \mathrm{~T}_{0}\right)$, yaitu sebesar 2.64 ton $\mathrm{C} /$ ha. Hal ini menunjukkan bahwa dengan adanya teras gulud dan tanaman penutup tanah mampu meningkatkan cadangan karbon tanah. Shofiyati et al., (2010), dan Ohkura et al., (2003) menyatakan bahwa kandungan karbon tanah dipengaruhi oleh sifat fisik tanah (terutama bulk density), serta jenis vegetasi yang tumbuh di atasnya. Tanaman merupakan tempat penyimpanan karbon dengan menyerap karbon dari udara melalui proses fotosintesis menjadi bahan penyusun jaringan tanaman. Pada saat daun, ranting, atau keseluruhan tanaman mati, bahan ini kemudian dikembalikan ke tanah, dan mengalami dekomposisi. Proses dekomposisi sebagian menghasilkan gas $\mathrm{CO}_{2}$ dan dilepaskan lagi ke udara, sedangkan sebagian lagi tertahan di dalam tanah (Robert, 2001).

Tabel 1. Pengaruh teras gulud dan penanaman tanaman penutup tanah terhadap cadangan karbon tanah (t/ha) di kebun kelapa sawit UU Rejosari PTPN VII, Lampung Selatan dari Agustus 2014 - April 2015.

\begin{tabular}{lcccc}
\hline \multirow{2}{*}{ Perlakuan } & \multicolumn{3}{c}{ Tanaman Penutup Tanah } & \multirow{2}{*}{ Rataan } \\
\cline { 2 - 4 } & $\mathrm{T}_{0}$ & $\mathrm{~T}_{1}$ & $\mathrm{~T}_{2}$ & \\
\hline Teras Gulud & & & & \\
$(\mathrm{G})$ & & & & \\
$\mathrm{G}_{0}$ & $2.64 \mathrm{f}$ & $4.44 \mathrm{e}$ & $5.28 \mathrm{~d}$ & $4.12 \mathrm{~b}$ \\
$\mathrm{G}_{1}$ & $7.04 \mathrm{c}$ & $10.45 \mathrm{~b}$ & $11.33 \mathrm{a}$ & $9.61 \mathrm{a}$ \\
\hline Rataan & $4.84 \mathrm{c}$ & $7.45 \mathrm{~b}$ & $8.30 \mathrm{a}$ &
\end{tabular}

Keterangan : Kolom dan baris yang sama diikuti oleh huruf yang tidak sama berbeda nyata pada taraf $5 \%$ berdasarkan uji BNT.

Nilai rataan yang diikuti oleh huruf yang tidak sama pada kolom atau baris yang sama berbeda nyata pada taraf $5 \%$ berdasarkan uji BNT.

$\mathrm{G}_{0}=$ tanpa guludan, $\mathrm{G}_{1}=$ dengan guludan, $\mathrm{T}_{0}=$ tanpa tanaman; $\mathrm{T}_{1}=$ tanaman $N$. biserrata; $\mathrm{T}_{2}=$ tanaman A. gangetica.

Lebih tingginya cadangan karbon tanah dengan adanya teras gulud dan tanaman penutup tanah karena rendahnya kejadian erosi dan aliran permukaan yang dapat menyebabkan hilangnya kandungan hara dan karbon tanah bersamaan dengan terjadinya erosi dan aliran permukaan pada saat musim hujan. Hasil penelitian Yenni et al. (2016a) menunjukkan bahwa perlakuan teras gulud dengan tanaman penutup tanah A. gangetica efektif menekan erosi sebesar $94.1 \%$ dan kehilangan hara $\mathrm{N}, \mathrm{P}, \mathrm{K}$ dibandingkan perlakuan tanpa teras gulud dan tanpa tanaman penutup tanah. Demikian pula hasil penelitian Ariyanti et al. (2016b) menunjukkan bahwa perlakuan teras gulud dengan tanaman penutup tanah $N$. biserrata efektif menekan aliran permukaan sebesar $95.7 \%$ dibandingkan perlakuan tanpa teras gulud dan tanaman penutup tanah.

Hairiah et al. (2011) menyatakan bahwa cadangan karbon tanah akan lebih besar apabila kesuburan tanahnya baik. Hasil penelitian Yenni et al. (2015b) menunjukkan bahwa kandungan hara $\mathrm{N}, \mathrm{P}, \mathrm{K}$ lebih tinggi pada tanah yang ditanam tanaman penutup tanah $N$. biserrata dan A. gangetica dibandingkan pada tanah tanpa 
tanaman penutup tanah berdasarkan neraca haranya, sehingga hal ini juga menyebabkan cadangan karbon tanah pada perlakuan dengan tanaman penutup tanah lebih tinggi dibandingkan cadangan karbon tanah pada perlakuan tanpa tanaman penutup tanah.

Pendugaan cadangan karbon tanah pada penelitian ini jauh lebih kecil dibandingkan dengan pendugaan cadangan karbon tanah penelitian Khasanah et al. (2015) pada perkebunan kelapa sawit perusahaan swasta dan perusahaan rakyat (plasma), yaitu berturutturut sebesar 42.07 ton $\mathrm{C} /$ ha dan 37.76 ton $\mathrm{C} /$ ha. Hal ini karena, pada penelitian ini, cadangan karbon tanah yang diukur hanya persentase kandungan C-organik di dalam tanah selama kurun waktu penelitian (Agustus 2014 - April 2015), tanpa menghitung cadangan karbon yang berasal dari biomasa tanaman penutup tanah dan pohon kelapa sawit.

Tabel 2. Pengaruh teras gulud dan penanaman tanaman penutup tanah terhadap bahan organik tanah (\%) di kebun kelapa sawit UU Rejosari PTPN VII, Lampung Selatan dari Agustus 2014 April 2015

\begin{tabular}{|c|c|c|c|c|}
\hline \multirow{2}{*}{ Perlakuan } & Tana & (1) & anah & \multirow[t]{2}{*}{ Rataan } \\
\hline & $\mathrm{T}_{0}$ & $\mathrm{~T}_{1}$ & $\mathrm{~T}_{2}$ & \\
\hline
\end{tabular}

Teras Gulud

(G)

\begin{tabular}{lllll}
$\mathrm{G}_{0}$ & $0.41 \mathrm{f}$ & $0.69 \mathrm{e}$ & $0.83 \mathrm{~d}$ & $0.64 \mathrm{~b}$ \\
$\mathrm{G}_{1}$ & $1.10 \mathrm{c}$ & $1.64 \mathrm{~b}$ & $1.78 \mathrm{a}$ & $1.51 \mathrm{a}$ \\
\hline Rataan & $0.75 \mathrm{c}$ & $1.16 \mathrm{~b}$ & $1.30 \mathrm{a}$ & \\
\hline
\end{tabular}

Keterangan : Kolom dan baris yang sama diikuti oleh huruf yang tidak sama berbeda nyata pada taraf $5 \%$ berdasarkan uji BNT.

Nilai rataan yang diikuti oleh huruf yang tidak sama pada kolom atau baris yang sama berbeda nyata pada taraf $5 \%$ berdasarkan uji BNT.

$\mathrm{G}_{0}=$ tanpa guludan, $\mathrm{G}_{1}=$ dengan guludan, $\mathrm{T}_{0}=\tan \mathrm{a}$ tanaman; $\mathrm{T}_{1}=\operatorname{tanaman} N$. biserrata; $\mathrm{T}_{2}=\operatorname{tanaman} A$. gangetica.

Dalam agroekosistem, bahan organik tanah sangat erat kaitannya dengan sifat fisik, kimia dan biologi tanah, serta berpengaruh dalam peningkatan kualitas dan produktivitas tanah. Bahan organic tanah juga berperan penting dalam meningkatkan ketersediaan air di dalam tanah, mempertahankan kesuburan tanah, sebagai pemasok utama unsur hara $\mathrm{N}$ dan hara lainnya untuk pertumbuhan tanaman (Smith et al., 2015). Bahan organik tanah juga merupakan kunci ketahanan tanaman terhadap kekeringan dan kelestarian produksi tanaman (Bot and Benites, 2005). Hasil analisis statistik bahan organik tanah pada perlakuan teras gulud dan tanaman penutup tanah disajikan pada Tabel 2.

Tabel 2 menunjukkan bahwa, kandungan bahan organik tanah lebih tinggi pada perlakuan teras gulud dan tanaman penutup tanah dibandingkan pada perlakuan tanpa teras gulud tanpa tanaman penutup tanah. Pada perlakuan teras gulud dan tanaman penutup tanah $A$. gangetica $\left(\mathrm{G}_{1} \mathrm{~T}_{2}\right)$ dan $N$. biserrata $\left(\mathrm{G}_{1} \mathrm{~T}_{1}\right)$, kandungan bahan organik tanah masing-masing sebesar $1.78 \%$ dan $1.64 \%$, sedangkan pada perlakuan tanpa teras gulud tanpa tanaman penutup tanah $\left(\mathrm{G}_{0} \mathrm{~T}_{0}\right)$ sebesar $0.41 \%$.

Kandungan bahan organik tanah tercermin dari kandungan karbon di dalam tanah dan merupakan indikator penting dalam pengelolaan tanah, sehingga apabila tanah mempunyai kandungan karbon tanah yang tinggi, menunjukkan bahwa tanah tersebut juga mempunyai kandungan bahan organik tanah yang tinggi pula. Hal ini terlihat pada hasil penelitian ini. Pada Tabel 1 terlihat bahwa tanah dengan teras gulud dan tanaman penutup tanah lebih tinggi cadangan karbon tanahnya dibandingkan pada tanah tanpa teras gulud tanpa tanaman penutup tanah. Demikian pula pada Tabel 2 terlihat bahwa kandungan bahan organic tanah lebih tinggi pada tanah dengan teras gulud dan tanaman penutup tanah dibandingkan pada tanah tanpa terasgulud tanpa tanaman penutup tanah.

Tingginya kandungan bahan organik tanah pada perlakuan teras gulud dan tanaman penutup tanah disebabkan sumber bahan organik tanah adalah biomasa tanaman, baik berupa serasah, sisa panen, ataupun pangkasan tanaman berupa hijauan. Peningkatan masukan biomasa tanaman ini dapat dilakukan dengan menngunakan tanaman penutup tanah dan rotasi tanaman (Supriyadi, 2008; Sharifi et al., 2014; St. Luce et al., 2016). Kandungan bahan organik di dalam tanah akan mempengaruhi pertumbuhan tanaman di atasnya. Pada penelitian ini, kandungan bahan organik di dalam tanah akan mempengaruhi pertumbuhan kelapa sawit (Tabel 3 dan 4).

Tabel 3 terlihat bahwa rata-rata panjang rachis pada perlakuan $\mathrm{G}_{1} \mathrm{~T}_{1}$ dan $\mathrm{G}_{1} \mathrm{~T}_{2}$ di bulan Agustus 2014 sampai April 2015 lebih banyak sebesar $2.60 \%$ dibandingkan perlakuan $\mathrm{G}_{0} \mathrm{~T}_{0}$. Hal ini disebabkan kandungan bahan organik tanah lebih tinggi pada perlakuan teras gulud dan 
tanaman penutup tanah (Tabel 2). Kandungan bahan organik tanah akan meningkatkan ketersediaan air dan hara dalam menunjang pertumbuhan pelepah kelapa sawit, karena kelapa sawit memproduksi pelepah rata-rata 2-3 pelepah sebulan apabila didukung oleh ketersediaan air dan hara sepanjang tahun (Hidayat et al., 2013).

Penurunan jumlah pelepah yang terjadi pada perlakuan $\mathrm{G}_{0} \mathrm{~T}_{0}$, tidak hanya disebabkan oleh kurangnya ketersediaan air dan hara pada bulan tersebut, tetapi juga disebabkan oleh kegiatan penunasan di kebun kelapa sawit. Penunasan merupakan kegiatan pembuangan pelepah tua yang tidak produktif pada kelapa sawit yang bertujuan untuk efisiensi distribusi fotosintat untuk pembungaan dan pembuahan, serta memudahkan pemanenan.

Selain disebabkan oleh penunasan, penurunan jumlah pelepah kelapa sawit juga disebabkan oleh banyaknya jumlah pelepah sengkleh atau patah pangkal pelepah. Pelepah sengkleh terjadi pada pelepah-pelepah terbawah yang terkulai dan patah pada pangkalnya. Menurut Purba (2009), penyebab pelepah sengkleh belum diketahui secara pasti, tetapi umumnya disebabkan oleh kekeringan dan ketidakseimbangan hara.

Terdapat perbedaan rata-rata jumlah pelepah sengkleh pada masing-masing perlakuan teras gulud dan tanaman penutup tanah (Tabel 4). Jumlah pelepah sengkleh dijumpai pada perlakuan tanpa teras gulud tanpa tanaman penutup tanah $\left(\mathrm{G}_{0} \mathrm{~T}_{0}\right)$ dan dengan teras gulud tanpa tanaman penutup tanah $\left(\mathrm{G}_{1} \mathrm{~T}_{0}\right)$, sedangkan pada perlakuan teras gulud dengan tanaman penutup tanah $\left(\mathrm{G}_{1} \mathrm{~T}_{1}\right.$, dan $\left.\mathrm{G}_{1} \mathrm{~T}_{2}\right)$ tidak terdapat pelepah sengkleh.

Pelepah sengkleh merupakan indikator tanaman kelapa sawit apabila mengalami kekeringan. Bulan Agustus 2014 merupakan bulan kering dengan tidak ada hujan sama sekali, sehingga pada bulan tersebut tanaman mengalami cekaman kekeringan. Terjadinya pelepah seng-kleh pada kelapa sawit akibat kekeringan disebabkan terjadinya perubahan potensial air, potensial osmotik dan potensial turgor sel yang mempengaruhi penutupan stomata, absorbsi dan translokasi hara, transpirasi, fotosintesis dan translokasi fotosintesis pada tanaman kelapa sawit (Kirkham, 1990). Akibatnya terjadinya pe-nurunan laju fotosintesis dan organ fotosintesis

Tabel 3. Rata-rata panjang pelepah, lebar pelepah, dan jumlah pelepah pada petak erosi di kebun kelapa sawit PTPN VII Rejosari, Lampung Selatan dari Agustus 2014 - April 2015*)

\begin{tabular}{|c|c|c|c|c|c|c|}
\hline \multirow[b]{2}{*}{ Bulan } & \multirow[b]{2}{*}{ Perlakuan } & \multicolumn{5}{|c|}{ Peubah Pertumbuhan } \\
\hline & & $\begin{array}{c}\text { Rata-rata } \\
\text { jumlah } \\
\text { pelepah }\end{array}$ & $\begin{array}{c}\text { Rata-rata } \\
\text { jumlah anak } \\
\text { daun }\end{array}$ & $\begin{array}{c}\text { Rata-rata } \\
\text { panjang anak } \\
\text { daun }(\mathrm{cm})\end{array}$ & $\begin{array}{c}\text { Rata-rata lebar } \\
\text { anak daun } \\
(\mathrm{cm})\end{array}$ & $\begin{array}{c}\text { Rata-rata } \\
\text { panjang rachis } \\
(\mathrm{m})\end{array}$ \\
\hline Agustus & $\mathrm{G}_{0} \mathrm{~T}_{0}$ & 41 & 352.00 & 94.14 & 5.01 & 6.50 \\
\hline \multirow[t]{5}{*}{2014} & $\mathrm{G}_{0} \mathrm{~T}_{1}$ & 41 & 352.04 & 94.27 & 5.05 & 6.50 \\
\hline & $\mathrm{G}_{0} \mathrm{~T}_{2}$ & 41 & 352.05 & 94.33 & 5.04 & 6.50 \\
\hline & $\mathrm{G}_{1} \mathrm{~T}_{0}$ & 41 & 352.04 & 94.08 & 5.03 & 6.50 \\
\hline & $\mathrm{G}_{1} \mathrm{~T}_{1}$ & 41 & 352.11 & 94.97 & 5.06 & 6.60 \\
\hline & $\mathrm{G}_{1} \mathrm{~T}_{2}$ & 41 & 352.11 & 94.81 & 5.07 & 6.60 \\
\hline Desember & $\mathrm{G}_{0} \mathrm{~T}_{0}$ & 40 & 352.31 & 94.18 & 5.02 & 6.50 \\
\hline \multirow[t]{5}{*}{2014} & $\mathrm{G}_{0} \mathrm{~T}_{1}$ & 40 & 352.64 & 94.75 & 5.06 & 6.55 \\
\hline & $\mathrm{G}_{0} \mathrm{~T}_{2}$ & 40 & 352.63 & 94.71 & 5.06 & 6.55 \\
\hline & $\mathrm{G}_{1} \mathrm{~T}_{0}$ & 40 & 352.64 & 94.21 & 5.03 & 6.50 \\
\hline & $\mathrm{G}_{1} \mathrm{~T}_{1}$ & 40 & 352.87 & 94.97 & 5.06 & 6.65 \\
\hline & $\mathrm{G}_{1} \mathrm{~T}_{2}$ & 40 & 352.88 & 94.95 & 5.06 & 6.65 \\
\hline April & $\mathrm{G}_{0} \mathrm{~T}_{0}$ & 43 & 353.51 & 94.46 & 5.03 & 6.53 \\
\hline \multirow[t]{5}{*}{2014} & $\mathrm{G}_{0} \mathrm{~T}_{1}$ & 43 & 353.55 & 94.95 & 5.07 & 6.54 \\
\hline & $\mathrm{G}_{0} \mathrm{~T}_{2}$ & 43 & 353.57 & 94.92 & 5.07 & 6.54 \\
\hline & $\mathrm{G}_{1} \mathrm{~T}_{0}$ & 43 & 353.62 & 94.16 & 5.04 & 6.54 \\
\hline & $\mathrm{G}_{1} \mathrm{~T}_{1}$ & 44 & 353.71 & 95.12 & 5.07 & 6.70 \\
\hline & $\mathrm{G}_{1} \mathrm{~T}_{2}$ & 44 & 353.72 & 95.12 & 5.07 & 6.70 \\
\hline
\end{tabular}

Keterangan : $\mathrm{G}_{0}=$ tanpa guludan, $\mathrm{G}_{1}=$ dengan guludan, $\mathrm{T}_{0}=$ tanpa tanaman; $\mathrm{T}_{1}=\operatorname{tanaman} N$. biserrata; $\mathrm{T}_{2}=$ tanaman A. gangetica.

*) Merupakan penelitian bersama Mira Ariyanti dengan kajian yang berbeda 
Tabel 4. Rata-rata jumlah pelepah sengkleh, luas daun, dan ILD pada petak erosi di kebun kelapa sawit PTPN VII Rejosari, Lampung Selatan dari Agustus 2014 - April 2015*)

\begin{tabular}{lcccc}
\hline \multirow{3}{*}{ Bulan } & Perlakuan & \multicolumn{3}{c}{ Peubah pertumbuhan } \\
\cline { 3 - 5 } & & $\begin{array}{c}\text { Rata-rata pumlah } \\
\text { pelepah sengkleh }\end{array}$ & $\begin{array}{c}\text { Rata-rata luas daun per } \\
\text { pohon }\left(\mathrm{m}^{2}\right)\end{array}$ & ILD \\
\hline \multirow{5}{*}{ Agustus 2014 } & $\mathrm{G}_{0} \mathrm{~T}_{0}$ & 19.00 & 9.21 & 5.41 \\
& $\mathrm{G}_{0} \mathrm{~T}_{1}$ & 1.30 & 9.22 & 5.41 \\
& $\mathrm{G}_{0} \mathrm{~T}_{2}$ & 1.00 & 9.22 & 5.41 \\
& $\mathrm{G}_{1} \mathrm{~T}_{0}$ & 5.30 & 9.22 & 5.41 \\
& $\mathrm{G}_{1} \mathrm{~T}_{1}$ & 0.00 & 9.23 & 5.41 \\
& $\mathrm{G}_{1} \mathrm{~T}_{2}$ & 0.00 & 9.23 & 5.41 \\
\hline & $\mathrm{G}_{0} \mathrm{~T}_{0}$ & 3.50 & 9.29 & 5.58 \\
& $\mathrm{G}_{0} \mathrm{~T}_{1}$ & 0.50 & 9.29 & 5.58 \\
& $\mathrm{G}_{0} \mathrm{~T}_{2}$ & 0.50 & 9.29 & 5.58 \\
& $\mathrm{G}_{1} \mathrm{~T}_{0}$ & 2.50 & 9.29 & 5.58 \\
& $\mathrm{G}_{1} \mathrm{~T}_{1}$ & 0.00 & 9.30 & 5.59 \\
\hline & $\mathrm{G}_{1} \mathrm{~T}_{2}$ & 0.00 & 9.31 & 5.62 \\
& $\mathrm{G}_{0} \mathrm{~T}_{0}$ & 3.00 & 9.36 & 5.62 \\
& $\mathrm{G}_{0} \mathrm{~T}_{1}$ & 0.00 & 9.36 & 5.62 \\
& $\mathrm{G}_{0} \mathrm{~T}_{2}$ & 0.00 & 9.36 & 5.62 \\
& $\mathrm{G}_{1} \mathrm{~T}_{0}$ & 2.00 & 9.36 & 5.63 \\
\hline & $\mathrm{G}_{1} \mathrm{~T}_{1}$ & 0.00 & 9.38 & \\
\hline & $\mathrm{G}_{1} \mathrm{~T}_{2}$ & 0.00 & 9.37 & \\
\hline
\end{tabular}

Keterangan : $\mathrm{G}_{0}=$ tanpa guludan, $\mathrm{G}_{1}=$ dengan guludan, $\mathrm{T}_{0}=$ tanpa tanaman; $\mathrm{T}_{1}=\operatorname{tanaman} N$. biserrata; $\mathrm{T}_{2}=$ tanaman A. gangetica.

*) Merupakan penelitian bersama Mira Ariyanti dengan kajian yang berbeda

(daun) mengalami penuaan dini, mengering dan patah yang bertujuan untuk mengurangi evapotranspirasi (Mahamooth et al., 2008). Sejalan dengan hasil penelitian Cha-um et al. (2010) yang menunjukkan bahwa tanaman kelapa sawit yang mengalami kekeringan menyebabkan penurunan potensial osmotik pada jaringan daun maupun pada jaringan akar, sehingga memacu kerusakan pigmen fotosintesis (klorofil) dan memperkecil kemampuan fotosintesis tanaman kelapa sawit.

Gambar 2 menunjukkan bahwa pada perlakuan tanpa teras gulud tanpa tanaman penutup tanah $\left(\mathrm{G}_{0} \mathrm{~T}_{0}\right)$, jumlah pelepah sengkleh dari bulan Agustus 2014 sampai April 2015 lebih banyak dibandingkan dengan perlakuan teras gulud dengan tanaman penutup tanah $\left(\mathrm{G}_{1} \mathrm{~T}_{1}\right.$ dan $\mathrm{G}_{1} \mathrm{~T}_{2}$ ). Hal ini disebabkan pada perlakuan $\mathrm{G}_{0} \mathrm{~T}_{0}$ terjadi defisit air yang cukup besar dibandingkan pada perlakuan $\mathrm{G}_{1} \mathrm{~T}_{1}$ dan $\mathrm{G}_{1} \mathrm{~T}_{2}$. Hasil penelitian Cha-um et al. (2013) menunjukkan bahwa kelapa sawit yang mengalami defisit air akan mengalami penurunan laju fotosintesis yang lebih besar karena terjadi penurunan klorofil, sehingga terjadi pengurangan tingkat fotosintesis bersih yang mengakibatkan daun mengalami kekeringan dan patah.

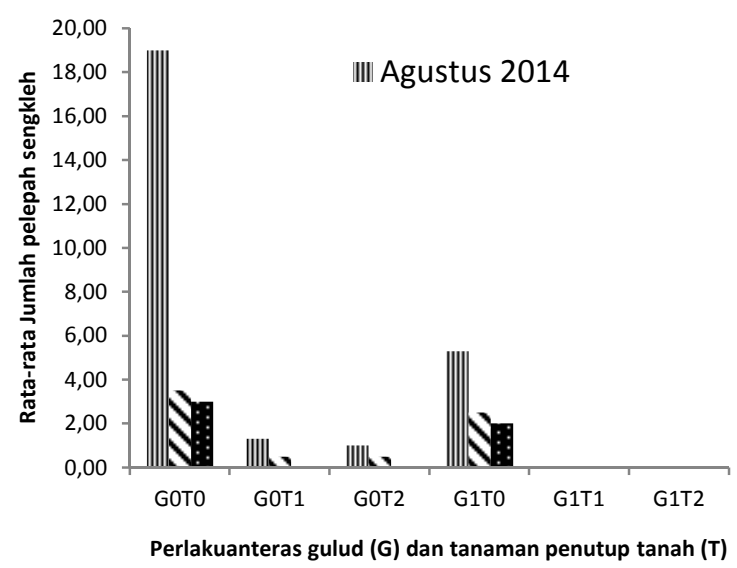

Gambar 2. Jumlah Pelepah Sengkleh Pada Bulan Agustus 2014, Desember 2014, dan April 2015 Berdasarkan Perlakuan Teras Gulud dan Tanaman Penutup Tanah.

Terjadinya defisit air yang cukup besar pada perlakuan $\mathrm{G}_{0} \mathrm{~T}_{0}$ dibandingkan pada perlakuan $G_{1} T_{1}$ dan $G_{1} T_{2}$ tercermin dari lebih rendahnya kandungan bahan organik tanah pada perlakuan $\mathrm{G}_{0} \mathrm{~T}_{0}$ dibandingkan kandungan bahan organik tanah pada perlakuan $\mathrm{G}_{1} \mathrm{~T}_{1}$ dan $\mathrm{G}_{1} \mathrm{~T}_{2}$ (Tabel 2). Lal (2006) menyatakan bahwa terdapat korelasi yang erat antara peningkatan 
bahan organik tanah dan kapasitas air tersedia sehingga tanaman mampu bertahan terhadap kekeringan. Supriyadi (2008) menyatakan bahwa peningkatan bahan organik tanah akan meningkatkan pertumbuhan tanaman budidaya yang disebabkan meningkatnya kapasitas air tersedia, suplai hara, dan struktur tanah dan sifat fisik lainnya.

ILD dan luas daun umumnya bersifat genetik dan akan meningkat dengan bertambahnya umur tanaman disebabkan bertambahnya jumlah dan ukuran anak daun. Hal ini terlihat pada Tabel 4 yang menunjukkan bahwa ILD dan luas daun kelapa sawit meningkat dengan meningkatnya curah hujan (Agustus 2014 sampai April 2015) pada semua perlakuan. Pada bulan Agustus 2014 merupakan bulan dengan tanpa curah hujan, maka ILD dan luas daun pada bulan tersebut lebih rendah dibandingkan dengan ILD dan luas daun pada bulan Desember 2014 dan April 2015. Bulan Desember 2014 sampai April 2015 merupakan bulan dengan curah hujan 100-200 mm per bulan pada perkebunan kelapa sawit di Kabupaten Natar, Lampung Selatan. Mahamooth et al. (2008) menyatakan bahwa mekanisme pertahanan kelapa sawit dalam menghadapi kekeringan salah satunya adalah dengan menurunkan pembukaan daun baru dan memperkecil ukuran daun sehingga luas daun berkurang.

\section{Kesimpulan}

1. Cadangan karbon tanah di perkebunan kelapa sawit lebih tinggi pada lahan dengan teras gulud dan tanaman penutup tanah $N$. biserrata dan $A$. gangetica, masing-masing sebesar 10.45 ton $\mathrm{C} /$ ha dan 11.33 ton C/ha, dibandingkan cadangan karbon tanah pada lahan tanpa teras gulud tanpa tanaman penutup tanah, yaitu sebesar 2.64 ton $\mathrm{C} / \mathrm{ha}$.

2. Bahan organik tanah di kebun kelapa sawit dengan teras gulud dan tanaman penutup tanah $N$. biserrata dan A. gangetica yaitu masing-masing sebesar $1.64 \%$ dan $1.78 \%$, lebih tinggi dibandingkan di kebun kelapa sawit tanpa teras gulud tanpa tanaman penutup tanah, yaitu sebesar $0.41 \%$.

3. Teras gulud dengan tanaman penutup tanah $N$. biserrata dan $A$. gangetica meningkatkan pertumbuhan kelapa sawit karena mempertahankan kelembaban tanah pada musim kering dengan lebih tingginya kandungan bahan organic dan cadangan karbon tanah terutama pada rataan panjang rachis dan rataan jumlah pelepah sengkleh.

\section{Ucapan Terima Kasih}

Kepada Pusat Penelitian Kelapa Sawit (PPKS) Medan, Sumatera Utara yang telah mendanai seluruh penelitian ini dan PT. Perkebunan Nusantara VII Lampung yang telah memberikan ijin lokasi penelitian.

\section{Daftar Pustaka}

Ariyanti, M., S. Yahya, K. Murtilaksono, Suwarto, H.H. Siregar. 2014. Potential use of Nephrolepis biserrata as cover crop under mature oil palm plantation. p.120-123. Proc. The 3rd International Conference on Multidisciplinary Research. Medan (ID): Universitas Islam Sumatera Utara.

Ariyanti, M., S. Yahya, K. Murtilaksono, Suwarto, H.H. Siregar. 2015a. Study of the growth of Nephrolepis biserrata Kuntze and its utilization as cover crop under mature oil palm plantation. International Journal of Sciences: Basic and Applied Research (IJSBAR) 19(1): 325-333.

Ariyanti, M., S. Yahya, K. Murtilaksono, Suwarto, H.H. Siregar. 2015b. Peranan tanaman penutup tanah Nephrolepis biserrata terhadap neraca air di perkebunan kelapa sawit Lampung Selatan. J. Pen. Kelapa Sawit 23 (2): 61-68.

Ariyanti, M., S. Yahya , K. Murtilaksono, Suwarto, H.H.Siregar. 2016a. Water balance in oil palm plantation with ridge terrace and Nephrolepis biserrata as cover crop. Journal of Tropical Crop Science 3 (2): 35-41.

Ariyanti, M. , S. Yahya , K. Murtilaksono, Suwarto, H.H.Siregar. 2016a. Pengaruh tanaman penutup tanah Nephrolepis biserrata dan teras gulud terhadap aliran permukaan dan pertumbuhan kelapa sawit (Elaeis guineensis Jacq.). Jurnal Kultivasi 15(2): 121-127.

Arsyad, S. 2010. Konservasi Tanah dan Air. Revisi ke-3. IPB Press. Bogor. 316p.

Bationo, A., J. Kihara, B. Vanlauwe, B. Waswa, J. Kimetu. 2006. Soil organic carbon dynamic, functions, and management in West African agroecosystems. Agriculture Systems. Elsevier.

Bot, A., J. Benites. 2005. The importance of soil organic matter key to drought resistant soil and sustained 
food and production. FAO Soils Bulletin 80, Rome.

Cha-um, S., T. Takabe, C. Kirdmanee. 2010. Osmotic potential, photosynthetic abilities and growth characters of oil palm (Elaeis guineensis Jacq.) seedlings in responses to polyethylene glycol-induced water deficit. African Journal of Biotechnology 9(39): 6509-6516.

Cha-um, S., N. Yamada, T. Takabe, C. Kirdmanee. 2013. Physiological features and growth characters of oil palm (Elaeis guineensis Jacq.) in response to reduced water-deficit and rewatering. Australian Journal of Crop Science 7(3): 432439.

Follett, R.F., J.M. Kimble, E.G. Pruessner, S. Samson-Liebig, S. Waltman. 2009. Soil Organic Carbon Stocks with Depth and Land Use at Various U.S. Sites. Chapter 3 In 'Soil Carbon Sequestration and the Greenhouse Effect'. (Coeditors, Lal R and Follett RF), Soil Science Special Publication 57, second ed. pp 29-46.

Gopal, T.K., G. Megha, D. Chamundeeswari, R.C. Umamaheswara. 2013. Phytochemical and pharmacological studies on whole plant of Asystasia gangetica. Indian J. of Research in Pharmacy and Biotechnology 1(3) : 365-370.

Hairiah, K., R.R. Sari, S. Rahayu, A. Ekadinata. 2011. Pendugaan Cadangan Karbon dari Tingkat Lahan ke Bentang Lahan. Bogor: World Agroforestry Centre, ICRAF Southest Asia.

Hardjowigeno, S. 2010. Ilmu Tanah. Edisi Revisi. Jakarta (ID): Mediayatama Sarana Perkasa.

Hidayat TC, Harahap IY, Pangaribuan Y, Rahutomo S, Fauzi WR, Harsanto WA. 2013. Bunga, buah, dan produksi kelapa sawit. Medan (ID): Pusat Penelitian Kelapa Sawit.

Hou, R., Z.O.Y. Li, D.D. Tyler, F. Li, G.F. Wilson. 2012. Effect of tillage and residue management on soil organic carbon and total nitrogen in the North China Plain. Soil \& Water Management \& Conservation. SSSAJ. 76(1).230-240.

Islam, K.R., R.R. Weil. 2000. Soil quality indicator properties in Mid-Atlantic Soils as influenced by conservation management. J. Soil and water Cons. 55(1): 69-78.

Kirkham, M.B. 1990. Plant responses to water deficits: In BA Stewart \& DR (Ed). Madison, Wisconsin (US): Irrigation of Agricultural Crops.

Khasanah N., M. van Noordwijk, H. Ningsih H. 2015. Aboveground carbon stocks in oil palm plantations and the threshold for carbon-neutral vegetation conversion on mineral soils. Cogent Environmental Science 1:1119964.
Lal, R. 2006. Enhancing crop yields in the developing countries through restoration of the soil organic carbon pool in agricultural lands. Land Degrad. Develop. 17: 197-209.

Liebig, M.A., A.J. Franzluebbers, R.F. Follett, et al. 2012. Agriculture and climate change: mitigation opportunities and adaptation imperatives. In: Liebig, M.A.(Ed.), Managing Agricultural Greenhouse Gases Coordinated Agricultural Research through GRACEnet to address our Changing Climate. Academic Press, New York, USA, pp. 3-11.

Liu, Z., M. Shao, Y. Wang. 2011. Effect of environmental factors on regional soil organic carbon stock across the losses plateau region, China. Agriculture, Ecosystems, and Environment. 142:184-194.

Lugina, M., K.L. Ginoga, A. Wibowo, A. Bainnaura and T. Partiani. 2011. Prosedur Operasi Standar untuk Pengukuran dan Perhitungan Stok Karbon di Kawasan Konservasi. Pusat Penelitian dan Pengembangan Perubahan Iklim dan Kebijakan Penelitian dan Pengembangan Kehutanan. Bogor. 28p

Mahamooth, T.N., H.H. Gan, K.K. Kee, K.J. Goh. 2008. Water requirements and cycling of oil palm. Sarawak (MY): Proceedings of Agronomy Crop Trust (ACT) Agronomic Principles and Practices of Oil palm Cultivation.

Maswar. 2009. Kecepatan dekomposisi biomassa dan akumulasi karbon pada konversi lahan gambut menjadi perkebunan kelapa sawit. Prosiding dan Lokakarya Nasional Inovasi Sumberdaya Lahan. Buku II: Teknologi Konservasi, Pemupukan, dan Biologi Tanah. Balai Besar Penelitian dan Pengembangan Sumberdaya Lahan Pertanian. Badan Penelitian dan Pengembangan Pertanian, Kementerian Pertanian. www.balittanah.litbang.deptan.go.id. Diakses 28 November 2013.

Miguez, F.E., G.A. Bollero. 2005. Review of corn yield response under winter cover cropping systems using meta-analytic methods. Crop Sci. 45 (2005): 2318-2329.

Murtilaksono, K., E.S. Sutarta, N.H. Darlan, Sudarmo. 2007. Penerapan teknik konservasi tanah dan air dalam upaya peningkatan produksi kelapa sawit. Prosiding HITI. Yogyakarta. Vol. IX : 311-314.

Muslim, A.S. 2008. Efektivitas teras gulud dan rorak dalam mengendalikan aliran permukaan dan erosi pada perkebunan kelapa sawit di unit usaha Rejosari, PT. Perkebunan Nusantara VII, 
Lampung. Skripsi. Program Studi Ilmu Tanah. Fak. Pertanian IPB. Bogor.

Ohkura, T., Y. Yokoi, H. Imai. 2003. Variations in soil organic carbon in Japanese arable lands. $\mathrm{p}$ 273-280. In Smith, C.A.S. (ed.) Soil Organic Carbon and Agriculture: Developing Indicators for Policy Analyses. Proceedings of an OECD expert meeting, Ottawa Canada.

Pratiwi, I. 2008. Pengaruh guludan dan rorak terhadap produksi kelapa sawit di unit usaha Rejosari PTPN VII. Lampung Selatan. Skripsi. Program Studi Ilmu Tanah. Fakultas Pertanian Institut Pertanian Bogor. Bogor.

Purba, R.Y. 2009. Penyakit-penyakit kelapa sawit (Elaeis guineensis Jacq) di Indonesia. Medan (ID): Pusat Penelitian Kelapa sawit.

Reicosky, D.C., F. Forcella. 1998. Cover crops and soil quality interaction in agroecosystem. J. Soil Water Conserv. 53: 224-229.

Robert, M. 2001. Soil Carbon Sequestration for Improved Land Management. Food and Agriculture Organization (FAO) of the United Nations. Rome. 75p.

Sharifi, M., B.J. Zebarth, J.J. Miller, D.L. Burton, C.A. Grant. 2014. Soil nitrogen mineralization in a soil with long-term history of fresh and composted manure containing straw or wood-chip bedding. Nutrient Cycling in Agroecosystems 99, 63e78. http://dx.doi.org/10.1007/s10705014-9618-9.

Shofiyati, R., I. Las, F. Agus. 2010. Indonesian Soil Data Base and Predicted Stock of Soil Carbon. Proc.of Int. Workshop on Evaluation and Sustainable Management of Soil Carbon Sequestration in Asian Countries. Bogor, Indonesia: 73-84.

Smith, P., M.F. Cotrufo, C. Rumpel, K. Paustian, P.J. Kuikman, J.A. Elliott, R. McDowell, R.I. Griffiths, S. Asakawa, M. Bustamante, J.I. House, A.J. Sobock, R. Harper, G. Pan, P.C. West, J.S. Gerber, J.M. Clark, T. Adhya, R.J. Scholes, M.C. Scholes. 2015. Biogeochemical cycles and biodiversity as key drivers of ecosystem services provided by soils. Soil 1, 665e685. http://dx.doi.org/10.5194/soil-1-665-2015.

Snapp, S.S., S.W. Swinton, R. Labarta, D. Mutch, J.R. Black, R. Leep, J. Nyiraneza, K. O'Neil. 2005. Evaluating cover crops for benefits, costs and performance within cropping system niches.
Agron. J. 97(2005): 322-332.

St. Luce, M., C.A. Grant, N. Ziadi, B.J. Zebarth, J.T. O'Donovan, R.E. Blackshaw, K.N. Harker, E.N. Johnson, Y. Gan, G.P. Lafond, W.E. May, S.S. Malhi, T.K. Turkington, N.Z. Lupwayi, D.L. McLaren. 2016. Preceding crops and nitrogen fertilization influence soil nitrogen cycling in no-till canola and wheat cropping systems. Field Crops Research 191, $20 \mathrm{e} 32$. http://dx.doi.org/10.1016/j.fcr.2016.02.014.

Supriyadi, S. 2008. Kandungan bahan organik sebagai dasar pengelolaan tanah di lahan kering Madura. Embryo 5(2): 176-183.

Tarnocai, C., J.G. Canadell, E.A.G. Schuur, P. Kuhry, G. Mazhitova, S. Zimov. 2009. Soil organic carbon pools in the northern circumpolar permafrost region. Global Biogeochemical Cycles 23, 11.

Yenni. A., S. Yahya , K. Murtilaksono, Sudradjat, E.S.Sutarta. 2014. The potency of Asystasia gangetica (L.) T. Anderson as cover crop under mature oil palm. Proceeding The 3rd International Conference on Multidisciplinary Research. Universitas Islam Sumatera Utara. Medan.

Yenni. A., S. Yahya , K. Murtilaksono, Sudradjat, E.S.Sutarta. 2015a. Study of Asystasia gangetica (L.) T. Anderson utilization as cover crop under mature oil palm with different ages. International Journal of Sciences: Basic and Applied Research (IJSBAR) 19(2): 137-148.

Yenni. A., S. Yahya , K. Murtilaksono, Sudradjat, E.S.Sutarta. 2015b. Peran tanaman penutup tanah terhadap neraca hara $N, P$, dan $\mathrm{K}$ di perkebunan kelapa sawit menghasilkan di Lampung Selatan. J. Pen. Kelapa Sawit 23 (2): 53-60.

Yenni. A., S. Yahya , K. Murtilaksono, Sudradjat, E.S.Sutarta. 2016a. The roles of Asystasia gangetica (L.) T. Anderson and ridge terrace in reducing soil erosion and nutrient losses in oil palm plantation in South Lampung, Indonesia. Journal of Tropical Crop Science 3 (2): 49-55.

Yenni. A., S. Yahya , K. Murtilaksono, Sudradjat, E.S.Sutarta. 2016b. Roles of Asystasia gangetica (L.) T. Anderson as cover crop on mature oil palm plantation. Proc. The 5th International Conf. on Multidisciplinary Research. Univ. Hasanuddin. Makassar 6-8th Sept., 2016. 